\title{
LA UNIDAD MÉDICA
}

$\mathrm{D}$

esde hace varios lustros hemos comentado que el pilar fundamental para la salvaguardia de nuestro ejercicio profesional, se basa en la unidad del cuerpo médico, pues de lo contrario iríamos indefectiblemente a ser unos asalariados más en el ejercicio de la profesión.

Pero el individualismo que siempre ha caracterizado nuestra formación universitaria, hizo posible que la iniciativa de ser los mismos médicos quienes dirigiéramos nuestro propio ejercicio se truncara, y lamentablemente nos vemos abocados a la explotación que en un principio ejerció el estado y que posteriormente ha pasado a particulares y a la iniciativa privada.

Pero sin lugar a dudas la privatización de la Medicina, que ya es una realidad, deberíamos haberla hecho nosotros mismos, cuando vimos que el Estado tan sólo era un ente que usufructuando nuestro trabajo pasó a ser un mal administrador pues apeló a recursos oscuros en los estamento de Seguridad Social, que al tornarlos en botín de caza en la distribución politiquera, avasallaron todo principio ético y moral, llegando al extremo que con contratos a término, cercenaba toda prestación social.

Así tan solo sea la mínima en la atención de salud, confirmado lo anterior por los colegas, quienes al demandar por la atención básica de alguna enfermedad, se les niega aunque sus pro- pios colegas los atiendan en las instalaciones donde prestan servicios.

La Academia Nacional de Medicina, con más de cien años de existencia, además de ser la entidad que vela por el nivel científico de la profesión médica, hiciera la perentoria tan anhelada unidad profesional La Federación Médica Colombiana, consultora por parte del gobierno en las políticas de salud y vigía de la Ética Médica con sus Colegios Médicos viere el momento propicio para lograrla. Ascofame orientadora del recurso médico especializado, ratificara que ante la medicina prepagada y los tiempo que corrían era imperante la compactación del cuerpo médico. La Asociación de Sociedades Científicas impulsadora del nivel científico-académico de las especialidades médicas, insistió en la necesidad urgente de la tan anhelada unión.

Por lo anteriormente anotado consideramos que en los actos de reconocimiento de las organizaciones gremiales del cuerpo médico en el Día Panamericano del Médico, ese clamor fuera unánime en el acto central de esa celebración.

Dr. Antonio Lomanto Morán

Dr. Hernando Gaitán Duarte

Editores de la Revista Colombiana de Obstetricia y Ginecología 